\title{
Engellilere Yönelik Ayrımcılık ve Makul Uyumlaştırma Kavramı
}

\author{
Enes Ersöz \\ Arş. Grv. Necmettin Erbakan Üniversitesi Hukuk Fakültesi Anayasa Hukuku ABD, eersoz@erbakan.edu.tr
}

\begin{tabular}{|c|c|}
\hline Makale Bilgileri & ÖZ \\
\hline Makale Geçmişi & ünümüzde engellilere yönelik yaklaşım, onların toplumsal hayata dahil edilmesi, diğer \\
\hline $\begin{array}{l}\text { Geliş: } 24.04 .2020 \\
\text { Kabul: } 01.09 .2020 \\
\text { Yayın: } 31.12 .2020\end{array}$ & $\begin{array}{l}\text { bireylerle eşit firsatlara sahip hale getirilmesi yönünde değişmektedir. Bu bağlamda } \\
\text { geçmişteki koruyucu ve bakıma muhtaç kişiler oldukları yönünde bakışın bugün değiştiği } \\
\text { söylenebilir. Engellilere yönelik yaklaşımın değişmesi hukuk cephesinde de birtakım } \\
\text { değişikliklerin yapılması ihtiyacını doğurmaktadır. Birçok uluslararası sözleşmede kendine }\end{array}$ \\
\hline Anahtar Kelimeler: & yer bulan ayrımcılık yasağı engelliler için de geçerlidir. Bu bağlamda Engelli Hakları \\
\hline Engelli hakları & Sözleşmesi ve Engelli Hakları Komitesi, engellilere yönelik ayrımcılığın önlenmesinde \\
\hline Sözleşmesi, & önemli rol oynamaktadır. Engellilerin toplumsal yaşama dahil edilebilmesi, hukuki anlamda \\
\hline Makul uyumlaştırma, & maruz kaldıkları ayrımcı yaklaşımların ortadan kaldırılmasıyla da ilişkilidir. Bu noktada \\
\hline $\begin{array}{l}\text { Makul düzenleme, } \\
\text { Ayrımcilık, }\end{array}$ & makul uyumlaştırma kavramı gündeme gelmektedir. Kavram özellikle dezavantajlı \\
\hline Engelli hakları & i yaklaşımların hukuki anlamda ortadan kaldırılması \\
\hline & $\begin{array}{l}\text { 1çın ortaya çıkmıştır. Aynı zamanda makul uyumlaştırmanın yapılmaması ayrımcılik } \\
\text { yasağına aykırı kabul edilmektedir. Böylece engellilerin ayrımcılığa karşı hukuki } \\
\text { güvenceleri artırılmak istenmektedir. }\end{array}$ \\
\hline
\end{tabular}

\section{Discrimination Against the Disabled and the Concept of Reasonable Accommodation}

\begin{tabular}{|c|c|}
\hline Article Info & ABSTRACT \\
\hline $\begin{array}{l}\text { Article History } \\
\text { Received: } \mathbf{2 4 . 0 4 . 2 0 2 0} \\
\text { Accepted: 01.09.2020 } \\
\text { Published: } \mathbf{3 1 . 1 2 . 2 0 2 0} \\
\text { Keywords: } \\
\text { Convention on the } \\
\text { rights of persons with } \\
\text { disabilities, } \\
\text { Reasonable } \\
\text { accommodation, } \\
\text { Reasonable adjustment, } \\
\text { Discrimination, } \\
\text { Committee on the rights } \\
\text { of persons with }\end{array}$ & $\begin{array}{l}\text { Today, the approach towards people with disabilities is changing to include them in social } \\
\text { life and to have equal opportunities with other individuals. In this context, it can be said that } \\
\text { the view that they are the people who need protection and care in the past has changed today. } \\
\text { Changing the approach towards the disabled creates the need to make some changes on the } \\
\text { legal front. The prohibition of discrimination found in many international conventions also } \\
\text { applies to disabled people. In this context, Convention on the Rights of Persons with } \\
\text { Disabilities and Committee on the Rights of Persons with Disabilities play an important role } \\
\text { in preventing discrimination against the disabled. The inclusion of people with disabilities } \\
\text { in social life is also related to the elimination of discriminatory approaches to which they } \\
\text { are legally exposed. At this point, the concept of reasonable accommodation comes up. The } \\
\text { concept has emerged to eliminate the inequality approaches to which disadvantaged groups } \\
\text { are exposed in a legal sense. At the same time, the lack of reasonable accommodation is } \\
\text { considered against the prohibition of discrimination. Thus, it is desired to increase the legal } \\
\text { guarantees of the disabled against discrimination. }\end{array}$ \\
\hline
\end{tabular}

disabilities.

Atıf/Citation: Ersöz, E. “Engellilere Yönelik Ayrımcılık ve Makul Uyumlaştırma Kavramı”, Necmettin Erbakan Üniversitesi Hukuk Fakültesi Dergisi, C. 3, S. 2, 2020, 149-163. 


\section{GİRIŞ}

Çalışmanın konusunu teşkil eden engellilere yönelik ayrımcı yaklaşımların halen geçerliliğini koruduğunu söylemek yanlış bir ifade olmayacaktır. Zira birçok devletin engelli bireylere yönelik hak ihlalleri yapmaya devam ettiği söylenebilir. Burada esasen engelli bireylerin dezavantajlı konumda bulunmalarından kaynaklı ortaya çıkan ihtiyaçlarının devletler tarafından karşılanmaması durumu söz konusudur.

Çalışmada ilk olarak engellilere yönelik uluslararası koruma mekanizmalarının neler olduğu ele alınmaktadır. Bu bağlamda önce Birleşmiş Milletler bünyesinde imzalanan sözleşmelerin yanında Türkiye'nin Avrupa İnsan Hakları Sözleşmesi (AİHS)'ni kabul etmesi sebebiyle Avrupa insan hakları anlayışı içerisinde ortaya çıkan koruma mekanizmaları incelenmektedir. Bu bağlamda sözleşmeler incelendikten sonra engellilere yönelik ayrımcılığa ilişkin Avrupa İnsan Hakları Mahkemesi (AİHM)'ne yapılan bazı başvurular ele alınmıştır. $\mathrm{Bu}$ yönüyle konunun, hukuk dogmatiği yaklaşımı ${ }^{1}$ ve jürisprüdansiyel ${ }^{2}$ bir yorumla incelendiği söylenebilir. Ayrıca çalışmayı engelli haklarına yönelik diğer çalışmalardan farklı kılacak husus, makul uyumlaştırma kavramına ilişkin yapılan incelemelerdir. Zira kavramın Türk hukuk mevzuatındaki karşıllğı ve uygulamada ne anlama geldiği açıklanmak istenmektedir. Nitekim Engelli Hakları Sözleşmesi de göz önünde bulundurulduğunda makul uyumlaştırma kavramının unsurlarının kavramlaştırılmasında birtakım sorunlar olduğu dikkat çekmektedir. Bu bakımdan makul uyumlaştırma kavramı, çalışmanın özgün değerini teşkil edecek noktalardan birisi olacaktır.

\section{Engelli Haklarına İlişkin Uluslararası Koruma Mekanizmaları}

\section{Engelli Hakları Sözleşmesi ve Engelli Hakları Komitesi}

Birleşmiş Milletler Genel Kurulu'nda 16 Aralık 1966 tarihinde kabul edilen Ekonomik, Sosyal ve Kültürel Haklara İlişsin Uluslararası Sözleşme (ESKHS), 10 Temmuz 2003 tarihli 2003/5923 sayılı Bakanlar Kurulu kararıyla onaylanmıştır ${ }^{3}$ Sözleşme'nin 2. maddesi 2. fikrası ayrımcılık yasağının şartlarını aşağıdaki şekilde belirlemiştir:

“Bu Sözleşme'ye Taraf Devletler, bu Sözleşme'de belirtilen hakların ırk, renk, cinsiyet, dil, din, siyasal ya da başka fikir, ulusal ya da toplumsal köken, mülkiyet, doğum ya da başka bir statü bakımından herhangi bir ayrım gözetilmeksizin uygulanmasını taahhüt eder."

Bunun dışında Sözleşme'nin 1994 tarihli 5 numaralı genel yorumu, engellilere ilişkin olmuştur. Söz konusu yorumda öncelikle engellilerin gelişmiş ülkelerde dahi Sözleşme kapsamında sahip oldukları hakların tam anlamıyla karşılanamadığı belirtilmiş, bu bağlamda dünyanın geniş bir bölümünde ilk olarak temel ihtiyaçlarının karşılanması gerekliliğine dikkat çekilmiştir ${ }^{4}$. Engelliliğe dayalı ayrımcıllğa gelince, 5 numaralı yorumda bunun de facto ve de jure biçimde ortaya çıkabildiği ifade edilmektedir 5 . Gerçekten de engelli bireylerin uğradığı ayrımcılık, kimi zaman söz konusu ülkenin iç hukukunda yer alan hükümlerin

1 Sağlam'a göre hukuk dogmatiği yaklaşımı, pozitif hukukun uygulanmasında ortaya çıkan sorunların ele alınması, bir başka deyişle incelenmesidir. Bu çalışmada pozitif hukuk kuralları üzerinden bir inceleme gerçekleştirilmekte olduğundan hukuk dogmatiği yaklaşımının benimsenmek istendiği söylenebilir. Hukuk kuramı-hukuk dogmatiği ayrımı için bkz. Sağlam, Fazıl. Temel Hakların Sınırlanması ve Özü, AÜSBF Yayınları, Ankara, 1982, s. 5-9.

2 Çağlar, Bakır. "Anayasa Yargısında Yorum Problemi Karşılaştırmalı Analizin Katkıları”, Anayasa Yargısı, C.2, 1985, s. 184 .

3 Sözleşmenin onaylanmasına dair karar 11 Ağustos 2003 tarihinde Resmî Gazete $(R G)$ 'de yayınlanmıştır. Bkz. RG, 11.08.2003-25196.

$4 \quad$ Uyar, Lema. Birleşmiş Milletler'de Insan Hakları Yorumları, İstanbul Bilgi Üniversitesi Yayınları, İstanbul, 2006, s. 152.

5 Uyar, s. 157-158. 
eşitliği sağlamaktan uzak yapısı dolayısıyla gerçekleşiyorken kimi zaman bu ayrımcılık hukuksal bir eksiklikten değil de fiili bir durumdan ötürü ortaya çıkabilmektedir.

Ekonomik, Sosyal ve Kültürel Haklara İlişkin Uluslararası Sözleşme’ye ek olarak engelli haklarının gelişimine koşut biçimde başka sözleşmeler de imzalanmakta, bu hakların güvence alanı genişletilmektedir. "Engelli Haklarına İlişkin Sözleşme" (EHS), bu ihtiyacın bir sonucu olarak imzalanmıştır .13 Aralık 2006 tarihli Birleşmiş Milletler Genel Kurulu'nda kabul edilen sözleşme, 3 Aralık 2008 tarihli ve 5825 sayılı Kanun'la uygun bulunmuş, 27 Mayıs 2009 tarihli Bakanlar Kurulu kararı ile 14 Temmuz 2009 tarihinde Resmî Gazete'de yayınlanmıştır?

$\mathrm{Bu}$ sözleşme kapsamında gerçekleştirilen korumaya geçmeden önce Engelli Hakları Komitesi'ne (Committee on The Rights of Persons with Disabilities) değinmekte fayda bulunmaktadır. Komite, dört yıllığına seçilen on sekiz bağımsız uzmandan oluşmaktadır. Bu uzmanlar vasıtasıyla sözleşmeye taraf devletlerin engelli haklarının teslim edilmesine ilişkin geldiği aşama denetlenmektedir. Devletler sözleşmeyi imzaladıktan sonra iki yıl içerisinde bu komiteye rapor verirler. Sonrasında ise dört yılda bir olmak üzere düzenli olarak rapor vermeye devam ederler. Komite, bu raporlardan yola çıkarak taraf devletlerin engelli haklarına ilişkin durumunu inceler ve tavsiyelerde bulunur ${ }^{8}$.

Engelli Hakları Komitesi'ne (EHK) Türkiye tarafından ilk rapor 2011 yılında sunulmuştur'. Raporun "Genel Hükümler" başlığı altında öncelikle Türkiye İstatistik Kurumu'nun hazırladığı veriler 1şığında Türkiye'deki engelli birey sayısının nüfusa oranı, engellerinin neye ilişkin olduğu gibi hususlara yer verilmektedir. Ayrıca Türk Ceza Kanunu'nda (TCK) birçok suç bakımından "beden veya ruh bakımından kendisini savunamayacak durumda bulunan kişiye karşı” işlenmesi durumunda cezasının artırılması öngörülmekte, dolayısıyla engelliliğe dayalı ayrımcı eylemler yaptırıma tabi tutulmaktadır. Başlığın devamında Türkiye, engelli bireylere karşı tutumunu değiştirdiğinden söz etmektedir. Zira 1960'l1 y1llarda yapılan kalkınma planlarında engelli bireyler bakıma muhtaç kişiler ${ }^{10}$ olarak tanımlanırken 1990'lardan sonra bu kişilerin sosyal hayata diğer bireyler gibi tam ve eşit bir şekilde katılımının sağlanması amaçlanmıştır. Bu bakımdan çalışmanın konusuyla da ilişkili olarak engelli bireylere bakış, ayrımcıllı̆ın önlenmesi amacına dönüşmektedir.

Raporun “Özel Hükümler” başlığı altında, EHS'nin her bir maddesi bakımından Türkiye'de ne gibi reformların yapıldığı ele alınmaktadır. Çalışmanın konusu bakımından ayrımcılık yasağına ilişkin yapılan reformlar önem arz etmektedir. Dolayısıyla 5. maddeye ilişkin başlık çalışma bakımından önem arz eden başlık olarak karşımıza çıkmaktadır. Burada TCK ve Milli Eğitim Temel Kanunu'nda yapılan değişikliklerden bahsedilmektedir ${ }^{11}$.

\footnotetext{
6 Ekonomik, Sosyal ve Kültürel Haklara İlişkin Uluslararası Sözleşme'de hiçbir ayrımın söz konusu olmadığı belirtilmiş olmasına rağmen engellilerin haklarının nasıl korunacağına dair somut bir metne ihtiyaç duyulduğundan Sözleşme'nin kabul edildiği de ifade edilmektedir. Bkz. Işıl Gül, İdil. "Birleşmiş Milletler Engelli Hakları Sözleşmesi”, Engellilik ve Ayrımcılık, Hazırlayanlar: Kenan Çayır, Melisa Soran, Melike Ergün, Karekök, İstanbul, 2015, s. 32.

$7 \quad R G, 14.07 .2009-27288$.

8 Committee on The Rights of Persons with Disabilities, "Questions and Answers", https://bit.ly/3ga6pnl, (Erişim Tarihi: 02.04.2020).

9 Türkiye tarafından Sözleşme'nin 35. Maddesi uyarınca sunulan ilk rapor 2011, https://bit.ly/312nseD, (Erişim Tarihi: 03.04.2020).

10 Bu yaklaşım yalnız Türkiye' de değil, uzun yıllar tüm dünyada bu şekilde olmuştur. Bkz. Çelik, Elif. “Onuncu Yılında Birleşmiş Milletler Engelli Kişilerin İnsan Hakları Sözleşmesi ve Sözleşme Ruhu”, INÜHFD, C.7, S.1, 2016, s. 221-222.

11 Eğitim hakkının herkes tarafından kullanılabileceğine ilişkin 4. maddede ayrım yapılamayacak hususlara “engellilik” kavramı da eklenmiştir. Bkz. RG, 24.06.1973-14574.
} 
Türkiye'nin sunduğu rapora karşılık Engelli Hakları Komitesi, 28 Mart 2019 tarihindeki 460. toplantısında nihai gözlemleri kabul ederek yayınlamıştır. Gözlem raporunda öncelikle Türkiye'nin bazı kanun ve kanun hükmünde kararnamelerde yaptığı değişiklikler ${ }^{12}$ ile 2010 anayasa değişikliğinde engellilere ayrımcılığa ilişkin alınan tedbirler takdir edilmektedir. Bunun dışında "Endişe veren başlıca alanlar ve tavsiyeler" başlığı altında bazı konulara dikkat çekilmektedir. Komite, öncelikle Türkiye'nin engellilere bakışının halen "ataerkil ve onları koruyucu" bir konumda yer aldığından söz etmektedir. Engelli bireyleri koruyucu yaklaşımın terk edilerek diğer bireyler gibi yaşamın tüm alanlarına katılımının sağlanması amacıyla mevcut mevzuatın gözden geçirilmesi tavsiye edilmektedir. Gözlem raporunun "Özel Haklar" başlığı altında eşitlik ve ayrımcılık yasağına ilişkin maddede ise mevzuatta yer alan ayrımcılığa yol açabilecek hükümlerin gözden geçirilmesi gerektiği belirtilmektedir. Özellikle vali, diplomat, hâkim, savcı ya da benzer bazı görevlerde gerekçelendirilmeksizin engelli bireylerin katılımının engellenmesinden endişe duyulduğu ifade edilmektedir. Bu kapsamda makul düzenlemelerin hayata geçirilmesi tavsiye edilmiştir ${ }^{13}$. Engelli Hakları Komitesi’ne başvuru imkânı sağlayan Ek Protokol, 03.12.2014 tarihinde onaylanmıştır ${ }^{14}$. Ancak Komite'ye Türkiye'den yapılan bir başvuru henüz bulunmamaktadır.

Sözleşmeye göre engeli olmayan bireylere göre sosyal hayata katılım sağlamakta güçlük çeken ve bu güçlüğü uzun süredir yaşayan kişi engelli statüsündedir. Zira engellilik kavramına yalnızca medikal bir bakış açısıyla yaklaşıımamışıı1 ${ }^{15}$. Bir başka deyişle sözleşmenin, yalnızca tıbbi rahatsızlıkları değil başka sosyal engellerin de engellilik bakımından değerlendirilmesi gerektiği şeklinde bir yaklaşımı söz konusudur. Böylelikle öğretide engellilere yaklaşımın ne şekilde olması gerektiğine yönelik medikal model-sosyal model tartışması bakımından sözleşmenin sosyal modeli benimsediği ifade edilebilir ${ }^{16}$.

Sözleşmeye bütüncül olarak bakıldığında, sözleşmenin yeni bir hak ihdas etme amacı gütmediği görülmektedir. Sözleşmenin asıl amacının engelli bireylere uygulanan ayrımcılığın önlenmesi, engelli bireylerin de engeli olmayan bireyler kadar eşit bir biçimde sosyal yaşama tam olarak katılımının sağlanması olduğu söylenebilir. Bu yönüyle düşünüldüğünde engellilere bazı konularda uygulanan pozitif ayrımcılık, sözleşme kapsamında eşitlik ilkesine ve ayrımcılık yasağına engel teşkil etmemektedir ${ }^{17}$.

Engelli haklarına ilişkin bir başka uluslararası koruma mekanizması ise Avrupa İnsan Hakları Sözleşmesi (AİHS) bünyesinde gerçekleşmektedir ${ }^{18}$.

Sözleşme'nin 1. maddesi şu şekildedir:

12 “Özürlüler” ifadesi, "engelliler” olarak değiştirilmiştir. Bkz.

https://www.lexpera.com.tr/mevzuat/kanunlar/engelliler-hakkinda-kanun-5378, (Erişim Tarihi:

04.04.2020).

13 Türkiye'nin İlk Raporuna İlişkin Nihai Gözlemler, http://www.tohad.org/tohad/wpcontent/uploads/2019/05/bmehs_nihai_gozlem_raporu_2019.pdf, (Erișim Tarihi: 04.04.2020).

$14 \quad$ Azarkan, Ezeli/Benzer, Ekrem. "Birleşmiş Milletler Engelli Kişilerin Haklarına Dair Sözleşme ve Türkiye'de Engelli Hakları”, DÜHFD, C.23, S.38, 2018, s. 5. Engellilerin Haklarına İlișkin Sözleşmeye Ek İhtiyari Protokolün Onaylanmasının Uygun Bulunmasına Dair 6574 s. Kanun. Bkz. RG, 12.12.2014-29203. Azarkan/Benzer, s. 6.

Öğretide engellilik modelleri olarak geçen bu tartışmada, temelde medikal modelle sosyal modelin ön plana çıktığ 1 ifade edilmektedir. Bu bağlamda sözleşmede medikal modelin engelliliği açıklamak için tek başına yeterli görülmediği söylenebilir. Engellilik modellerine ilişkin bkz. Erten, Şerafettin/Aktel, Mehmet.

"Engellilik Kültürü: Engellilik Modelleri Çerçevesinde Bir Değerlendirme", Sosyal Bilimlerde Kültür Tartı̧̧maları, Editör: Cem Ergun, Süleyman Öğrekçi, Gece Kitaplı̆̆ı, Ankara, 2017, s. 85.

Azarkan/Benzer, s. 9.

Türkiye'de de Avrupa İnsan Hakları Konvansiyonu'nun referans norm olarak kullanıldığı kabul edilmektedir. Dolayısıyla çalışmada Avrupa İnsan Hakları Konvansiyonu bağlamında engellilere ilişsin korumanın incelenmesi yerinde bir yaklaşım olacaktır. Referans norm meselesine ilişkin Bkz. Çağlar, s. 170. 
“Yüksek Sözleşmeci Taraflar kendi yetki alanları içinde bulunan herkesin, bu Sözleşme’nin birinci bölümünde açılklanan hak ve özgürlüklerden yararlanmalarını sağlarlar."

Sözleşme'nin 1. maddesinde yer alan "herkesin" ifadesi herhangi bir ayrım gözetilemeyeceği konusunu garanti altına almaktadır. Bunun dışında yine Sözleşme'nin 14. maddesi doğrudan ayrımcılık yasağına ilişkindir:

“Bu Sözleşme'de tanınan hak ve özgürlüklerden yararlanma, cinsiyet, ırk, renk, dil, din, siyasal veya diğer kanaatler, ulusal veya toplumsal köken, ulusal bir azınliğa aidiyet, servet, doğum başta olmak üzere herhangi başka bir duruma dayalı hiçbir ayrımcılık gözetilmeksizin sağlanmalıdır."

Görüldüğg̈ üzere AİHS'nin ilgili hükümlerine dayanarak engelli haklarının korunması mümkün olacaktır. Bunun dışında AİHS'ye Ek 12 numaralı protokol ayrımcılığın engellenmesine ilişkin olarak kabul edilmiştir. Ek Protokol 1 Nisan 2005 tarihinde yürürlüğe girmiştir. Türkiye tarafindan söz konusu protokol 18 Nisan 2001 tarihinde imzalanmış fakat onaylanmasına dair kanun henüz yürürlüğe girmemiştir ${ }^{19} .12$ numaralı protokolde "engelliler" ifadesine yer verilmemekle birlikte her türlü ayrımcılığın yasaklandığı kabul edilmektedir. Dolayısıyla söz konusu protokol, engellileri de koruma altına almaktadır.

Avrupa Birliği (AB) Konseyi (European Council)'nin engellilere yönelik aldığı birtakım kararlar bulunmaktadır. Bu kararlar bütüncül olarak incelendiğinde söz konusu kararların çalışma hayatı ve eğitim hakkı üzerinde yoğunlaştı̆̆ söylenebilir ${ }^{20}$. Zira engellilerin söz konusu alanlarda önemli ölçüde ayrımcılı̆̆a uğradığ

AB Konseyi’nin Türkiye’ye ilişkin raporlarında da engelli hakları konusuna değinilmektedir. 1998 yılından itibaren Avrupa Komisyonu tarafından Türkiye hakkında hazırlandığı görülen ilerleme raporlarında ${ }^{21}$ Türkiye'de engellilerin durumundan ilk olarak 2000 y1lı raporunda bahsedilmektedir. $\mathrm{Bu}$ raporda ülkenin içerisinde bulunduğu mali sıkıntılarla da ilişkili olarak engellilere ilişkin sosyal güvenlik sistemlerinin yetersiz olduğu ifade edilmektedir ${ }^{22}$. Raporlar incelemeye tabi tutulduğunda ilk olarak 2003 yılında ilerlemelerin kaydedildiği görülmektedir. Zira 2003 yılındaki raporda İş Kanunu'nda değişiklik yapıldığı, belli şartlar dahilinde engelli çalıştırmanın zorunlu hale getirildiği hususuna dikkat çekilmektedir ${ }^{23}$. Sonraki yıllarda düzenlenen raporlarda da Türkiye'nin birtakım iyileştirmeler yaptığı anlaşılmaktadır.

Uluslararası koruma bakımından dikkat çeken bir başka belge Gözden Geçirilmiş Avrupa Sosyal Şartı'dır. 1 Temmuz 1999 tarihinde yürürlüğe giren belgenin Türkiye'de yürürlüğe girmesi ise 1 Ağustos 2007 tarihinde gerçekleşmiştir. 27 Eylül 2006 tarihli 5547 sayı1ı Kanunla onaylanması uygun bulunan belgenin Türkçe çevirisi Bakanlar Kurulu'nun 22 Mart 2007 tarihli kararıyla, 9 Nisan 2007 tarihinde Resmî

Avrupa İnsan Hakları Sözleşmesi'ne Ek 12 Numaralı Protokol, https://bit.ly/34rs60b, (Erişim Tarihi: 22.05.2020).

20 Söz konusu kararlar, Görme Özürlüler Derneği ve Türkiye Kas Hastalıkları Derneği ortak projesi kapsamında hazırlanan bir rapordan incelenmiştir. Bkz. Akbulut, Süleyman/Özgül, Hakan/Polat, Güler. Engelli Ayrımcıllğg Araştırması ve Engelli Ayrımcılığına Karş̧ Çözüm Önerileri Raporu, Engelli Ayrımcilığını Önleme ve Mücadele Platformu, y.y., 2012, s. 170-171.

21 T.C. Dişişleri Bakanlığı Avrupa Birliği Başkanlığı, "Avrupa Komisyonu Tarafından Hazırlanan Türkiye Raporları”, https://www.ab.gov.tr/ilerleme-raporlari_46224.html, (Erişim Tarihi: 22.05.2020).

22 T.C. Dışişleri Bakanlığı Avrupa Birliği Başkanlığı, “Türkiye’nin Katılım Yönünde İlerlemesi Üzerine Komisyon'un 2000 Düzenli Raporu”, https://www.ab.gov.tr/files/AB_Iliskileri/AdaylikSureci/IlerlemeRaporlari/Turkiye_Ilerleme_Rap_2000.pdf , (Erişim Tarihi: 22.05.2020), s. 38.

23 T.C. Dışişleri Bakanlığı Avrupa Birliği Başkanlığı, “Türkiye'nin Avrupa Birliğine Katılım Sürecine İlişkin 2003 Yilı İlerleme Raporu", https://www.ab.gov.tr/files/AB_Iliskileri/AdaylikSureci/IlerlemeRaporlari/Turkiye_Ilerleme_Rap_2003.pdf , (Erişim Tarihi: 22.05.2020), s. 33. 
Gazete'de yayınlanmıştır ${ }^{24}$. Bu metinde engellilere doğrudan yer verilen 9, 10 ve 15 . maddeler bulunmaktadır. Mesleğe yöneltilme ve mesleki eğitim hakkı başlıklı 9. ve 10. maddelere göre engelliler de dahil olmak üzere herkesin meslek edinme ve bu mesleğin gereklerini yerine getirebileceği, mesleğini geliştirebileceği şartların sağlanmasının Akit Devletlerin yükümlülüğü altında olduğu belirtilmektedir. Doğrudan engellilere yönelik Akit Devletlere yükümlülükler yükleyen 15. madde ise aşağıdaki şekildedir:

"Akit Taraflar, yaşları ve özürlerinin nedenleri ve niteliği ne olursa olsun, özürlülerin toplumsal yaşamda bağımsız olma, sosyal bütünleşme ve katılma hakkını etkili bir biçimde kullanabilmelerini sağlamak amacıyla:

1- $\quad$ Mümkün olduğunda genel plan çerçevesinde, ya da bu mümkün değilse, kamusal ya da özel uzmanlaşmış organlar aracılığlyla özürlülerin yönlendirilmesini, öğrenimini ve mesleki ĕgitimini sağlamak için gerekli önlemleri almayl;

2- $\quad \quad \quad \quad$ Normal çalışma ortamında özürlüleri istihdam etmek ve onların istihdamını sürdürmek ve çalışma koşullarını özürlülerin gereksinimlerine uyarlamak, ya da özürlülük nedeniyle bunun mümkün olmadı̆̆ı durumlarda çalışmayı buna göre düzenlemek ya da özrün düzeyine göre güvenli bir istihdam türü yaratmak için, işverenleri özendirmeye yönelik bütün önlemlerle onların istihdam edilmelerini teşvik etmeyi; Bazı durumlarda bu önlemler uzmanlaşmış yerleştirme ve destekleme hizmetlerine başvurmayı gerekli kllabilir.

3- $\quad$ Özellikle, teknik yardımları da içermek üzere, iletişim ve hareket engellerinin üstesinden gelmeyi ve ulaşım, barınma, kültürel etkinlikler ve boş zaman kullanımını sağlamayı hedefleyen önlemler yoluyla özürlülerin toplumla tam olarak bütünleşmelerini ve toplum yaşamına katılmalarını teşvik etmeyi; taahhüt ederler."

15. madde ve yukarıda belirtilen 9. ve 10. maddelerin, belgenin 1. maddesinde geçen çalışma hakkı bakımından ayrımcılığın önlenmesine ilişkin olduğu söylenebilir ${ }^{25}$. Hatta metnin bütününde çalışma hakkına ilişkin düzenlemeler görülmektedir. Dolayısıyla söz konusu metin, engellilerin toplumsal hayata dahil edilmesi açısından önem arz etmektedir.

\section{Engellilere Yönelik Ayrımcılığa İlişkin Avrupa İnsan Hakları Mahkemesi’nin Bazı Kararları}

Birleşmiş Milletler bünyesinde Engelli Hakları Komitesi’nin kurulduğu yukarıda ifade edilmiştir. Komite'nin bir görevi akit devletlerin sözleşmeden kaynaklanan yükümlülüklerini yerine getirip getirmediği hususunda rapor düzenleme ve denetleme görevinin yanı sıra akit devletlerin bireylere karşı yükümlülüklerini yerine getirmedikleri hallerde yapılacak başvuruyu da inceleme yetkisini haizdir. Komite'ye bugüne kadar Türkiye'den yapılarak karara bağlanmış bir başvuru bulunmamaktadır ${ }^{26}$. Dolayısıyla çalışmanın bu bölümünde AİHM'ye yapılan başvuruların incelenmesi, daha yerinde olacaktır. Zira her ne kadar engellilerin adalet hizmetlerine erişimi noktasında yetersizliklere ilişkin tartışmalar devam etse de AİHM'ye engelliler tarafından yapılan başvurular bulunmaktadır.

AİHM kararlarının engellilere ilişkin kararları incelendiğinde, bu başvuruların genel olarak çalışma ve eğitim hakkına ilişkin başvurular olduğu görülmektedir. Dolayısıyla çalışmanın bu bölümünde söz konusu haklara ilişkin kararlar incelemeye tabi tutulmuştur. Bu kararların önemli bir çoğunluğunda özel hayata saygı hakkı bağlamında ayrımcılık yasağına aykırılık olup olmadığına bakılmaktadır. Zira engellilere ilişkin alınması gereken birtakım tedbirlerin, makul düzenlemeler yapma ihtiyacı gibi,

\footnotetext{
$24 \quad R G, 09.04 .2007-26488$.

25 Erdoğan, Gülnur. “Avrupa Sosyal Şartı ve Gözden Geçirilmiş Avrupa Sosyal Şartı”, TBB Dergisi, S.77, 2008, s. 141.

26 Bkz. Committee on the Rights of Persons with Disabilities, "Engelli Hakları Komitesi Bekleyen Davalar Tablosu”, https://www.ohchr.org/Documents/HRBodies/CRPD/Tablependingcases.pdf, (Erişim Tarihi: 24.05.2020).
} 
alınmamasından kaynaklı olarak engelli bireylere ayrımcılık yapıldığı iddiası mahkeme tarafindan incelenmiştir.

Bu bağlamda ilk olarak Botta v. İtalya kararı incelenebilir. Başvurucu engelli bir İtalyan vatandaşıdır. Commacchio tatil beldesindeki özel plajlarda engelliler için gerekli araçların (özel rampalı lavabo tuvalet vb.) bulunmadığından bahisle ilgili idareye başvuruda bulunmuş fakat yanıt alamamıştır ${ }^{27}$. Sonraki yıl aynı bölgeye tekrar gittiğinde herhangi bir değişiklik yapılmadığını gören başvurucunun, görevi ihmal gerekçesiyle belediye başkanı, liman müdürü vb. yetkililer hakkında bulunduğu şikayete ilişkin ise savcılık tarafından takipsizlik kararı verilmiştir ${ }^{28}$. Mahkeme'nin önüne gelen başvuruda başvurucu özel yaşama saygı hakkı bağlamında ayrımcılık yasağının ihlal edildiği, devletin pozitif yükümlülüğünü yerine getirmediği iddiasında bulunmuştur. Ancak Mahkeme, başvuruda başvurucunun ikamet yeri ile özel plajın uzak mesafelerde yer aldığını, dolayısıyla bu konuda devletin pozitif yükümlülügünün bu kadar geniş ve belirsiz olamayacağını belirterek 8. maddenin uygulanamayacağına koşut olarak ayrımcılık yasağını düzenleyen 14. maddenin de uygulanamayacağı, dolayısıyla özel yaşama saygı hakkının ihlal edilmediği yönünde karar vermiştir ${ }^{29}$.

Glor v. Ísviçre kararında ise başvurucu diyabet hastalığı dolayısıyla askeri hastane raporuyla askerlik hizmetine alınmamış, 1999 yılında ise sivil koruma servisi zorunluluğundan muaf tutulmuştur ${ }^{30}$. Ancak söz konusu muaf tutma kararı 2000 yılında kaldırılmış ve başvurucuya askerlik hizmetinden muafiyet vergisi tarh edilmiştir ${ }^{31}$. Başvurucu, askerlik hizmetini yapmaya hazır olduğunu söylemesine rağmen engelliliğinin \%40'ın altında olduğu gerekçesiyle bu talebi reddedilerek vergiden muafiyeti sağlanmamıştır. Mahkeme söz konusu başvuruda, vergiyi ödemekten muaf tutulanlar ile hizmete uygun olmayanlar arasında yapılan ayrımı haklı göstermek için yerel makamların yeterli gerekçe gösteremediği ve adil dengeyi kuramadığından bahisle AİHS'nin 8. ve 14. maddelerinin ihlal edildiği yönünde karar vermiştir ${ }^{32}$.

Bayrakçı v. Türkiye kararında başvurucu \%60 engelli, vergi dairesinde çalışan bir memurdur. Çalıştığı bölümde engelli tuvaleti bulunmadığından bahisle (erkek birey olan engelli başvurucuya uygun erkek tuvaleti bulunmadığı belirtilmiş) idareye dilekçe yazarak talepte bulunmuştur. Bir başka dilekçesinde ise çalıştığı bölümün yoğun hareket gerektirdiğini, kendisinin ise bunu karşılayamadığını dolayısıyla diğer engellilerle arasında ayrımcılık yapıldığını dile getirmiştir ${ }^{33}$. Başvurucunun iddialarına ilişkin ilgili kurumun müdürü, öncelikle engelli bireyin engeline uygun, oturarak yapılabilecek işler verildiğini dile getirmiştir. Tuvalete ilişkin ise söz konusu işyerinde engelli bireylere uygun tuvaletin erkek tuvaletinde bulunmadığı ancak idareden talepte bulunulduğunu, kadın tuvaletinde mevcut olduğunu, başvurucunun orayı kullanabileceğini dile getirmiştir ${ }^{34}$. İlgili idareden sonuç alamayan başvurucu, konuyu adli makamlara taşımış fakat adli makamlar da gerek görev tanımına ilişkin gerekse tuvalet konusuna ilişkin ilgili idare ve müdürün ayrımcılık saikiyle hareket etmediği yönünde karar almış, bunun üzerine açılan tazminat davası reddedilmiştir ${ }^{35}$.

AİHM'ye yapılan başvuruda Mahkeme, engelli bireyin bedensel engeline uygun tuvalet tesis edilmemesinin kişinin günlük hayatında ciddi sorunlar meydana getirebileceğinden, özel yaşama sayg1

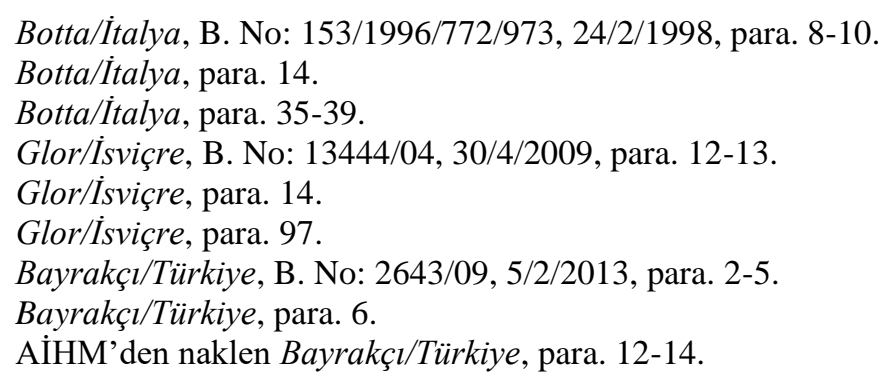


hakkı ile bağlantılı olarak ayrımcılık yasağı bakımından konuyu ele almıştır ${ }^{36}$. Bununla birlikte Mahkeme başvurucunun iç hukuk yollarını tüketmediğini kabul etmektedir. Mahkeme'ye göre başvurucu yalnızca müdüre tazminat davası açmıştır. Ancak anılan olayda devletin pozitif yükümlülüğüne ilişkin bir durum söz konusudur ${ }^{37}$.

Yakın tarihli Çam v. Türkiye kararında bu kez eğitim hakkına ilişkin bir başvuru söz konusu olmuştur. Söz konusu başvuruda İstanbul Teknik Üniversitesi Konservatuarı'na giriş sınavını kazanan görme engelli bireyin, Konservatuar'a kayıt şartlarını (söz konusu eğitimi almaya engeli bulunmadığ 1 yönünde sağlık raporu) sağlamadığ1 gerekçesiyle kaydı yapılmamıştır ${ }^{38}$. Bunun üzerine engelli bireyin ebeveynleri yürütmenin durdurulmasına ilişkin başvurularda bulunmuş fakat ilgili yargı makamları bu talebi reddetmiştir ${ }^{39}$. Danıştay’a yapılan başvuru da reddedilmiştir ${ }^{40}$.

AİHM'nin önüne gelen başvuruda, yerel makamların engelli bireyin ihtiyaçlarını tespit etmeye çalışmadıkları ifade edilmiştir. Oysa yerel makamların engelli bireyin ihtiyaçlarını tespit edip, söz konusu müzik eğitimini alabilmek için bu engellilik oranının ne kadar etkili olacağını belirtmesi gerekmektedir. Nitekim EHS ve Gözden Geçirilmiş Avrupa Sosyal Şartı'nda da belirlendiği üzere Akit Devletlerin makul düzenleme yükümlülüğü bulunmaktadır. Mahkeme de buna atıfta bulunarak söz konusu başvuruda yerel makamların gerekli araştırmayı yapmadığını belirlemiştir ${ }^{41}$.

Engelli bireylere ilişkin AİHM'ye yapılan birçok başvuru bulunmakla birlikte çalışmada, diğerlerine emsal nitelikte olan kararlara yer verilmekle yetinilmiştir. Dolayısıyla Mahkeme'ye yapılan başvurulara bütüncül olarak bakıldığında genel itibariyle özel yaşama saygı hakkına ilişkin başvurularla birlikte eğitim hakkına ilişkin başvuruların olduğu görülmektedir. Mahkeme bu başvurularda yalnızca Avrupa İnsan Hakları Sözleşmesi ile sınırlı kalmamış, BM bünyesinde kabul edilen Engelli Hakları Sözleşmesi'ne de atıfta bulunmuştur. Dolayısıyla Mahkeme'nin yaptığı incelemelerde dikkat çektiği nokta, engelli bireylere engelli olmaları sebebiyle bir ayrımcılık yapılıp yapılmadığını tespitine ek olarak davalı devletlerin başvuru konusuna ilişkin makul düzenleme yükümlülüğü olup olmadığı ve bunu yerine getirip getirmediğini tespit şeklinde ifade edilebilir.

\section{Engellilere İlişkin İ̧ Hukukta Yer Alan Hükümler ve Koruma Mekanizması}

Engelli Hakları Sözleşmesi olmasaydı dahi, engellilere yönelik ayrımcılık, Türkiye'nin Avrupa İnsan Hakları Sözleşmesi'ni kabul etmesi bakımından düşünüldüğünde AİHS'nin 1. maddesine dayanarak engellenebilecektir. Ayrıca Gözden Geçirilmiş Avrupa Sosyal Şartı'nın ilgili maddeleri de yukarıda belirtilmiş, bu hükümlerin engellilere yönelik ayrımcıllı̆̆ engellemeyi de hedeflediği dile getirilmiştir.

Uluslararası bağlamda belirlenen bu amaç ve izlenen yolun, iç hukukta da takip edildiği görülmektedir. Bir defa Anayasa'nın 12. maddesinin 1. fikrası şu şekildedir: "Herkes, kişiliğine bağll, dokunulmaz, devredilmez, vazgeçilmez temel hak ve hürriyetlere sahiptir.” İç hukukta başkaca hiçbir düzenleme yer almasa dahi bu hükme dayanılarak engellilerin hakları korunabilir. Zira hükümdeki "herkes" ifadesi din, dil, ırk, engellilik ve bunlara benzer başkaca bir ayrım gözetilmeksizin her bireyin kişilik haklarının anayasal koruma altında olduğunu ifade etmektedir. Bundan başka Anayasa'nın 10. maddesinin 1. fikrasında "Herkes, dil, ırk, renk, cinsiyet, siyasi düsünce, felsefi inanç, din, mezhep ve benzeri sebeplerle

\footnotetext{
36 Bayrakçı/Türkiye, para. 26-27.

37 Bayrakçı/Türkiye, para. 29.

38 Çam/Türkiye, B. No: 51500/08, 23/2/2016, para. 14.

39 Çam/Türkiye, para. 20.

40 Danıştay başsavcısı ise mahkemeye verdiği mütalaada başvuranın kaydının yapılmamasının anayasal ve yasal hükümlere aykırı olduğunu ve dolayısıyla iptal edilmesi gerektiğini belirtmiştir. Bkz. Çam/Türkiye, para. 32.

41 Çam/Türkiye, para. 68
} 
ayırım gözetilmeksizin kanun önünde eşittir. ” hükmü yer almaktadır. Bu hüküm ve maddeye 2010 anayasa değişikliği ile eklenen "Çocuklar, yaşlılar, özürlüler, harp ve vazife şehitlerinin dul ve yetimleri ile malul ve gaziler için alınacak tedbirler eşitlik ilkesine aykırı sayılmaz." fikrasıyla birlikte herhangi bir ayrımın kanun önünde mümkün olmadığı ve engelliler için alınacak tedbirlerin ayrımcılık sayılmayacağı ifade edilmektedir ${ }^{42}$. Kanun önünde eşitlik ilkesi birçok Anayasa Mahkemesi kararında da şu şekilde tanımlanmıştır:

“Anayasa'nın anılan maddesinde belirtilen kanun önünde eşitlik ilkesi hukuksal durumları aynı olanlar için söz konusudur. Bu ilke ile eylemli değil hukuksal eşitlik öngörülmüştür. Eşitlik ilkesinin amacı; aynı durumda bulunan kişilerin kanunlar karşısında aynı işleme bağlı tutulmalarını sağlamak, kişilere ayrım yapılmasını ve ayrıcalı taninmasinı önlemektir. Bu ilkeyle aynı durumda bulunan kimi kişi ve topluluklara ayrı kurallar uygulanarak kanun karşısında eşitliğin ihlali yasaklanmıştır. Kanun önünde eşitlik, herkesin her yönden aynı kurallara bağlı tutulacağı anlamına gelmez. Durumlarındaki özellikler, kimi kişiler ya da topluluklar için değişik kuralları ve uygulamaları gerektirebilir. Aynı hukuksal durumlar aynı, ayrı hukuksal durumlar farklı kurallara bağlı tutulursa Anayasa'da öngörülen eşitlik ilkesi zedelenmez. "³

Gerçekten de ayrımcılık yasağı ilkesi için eşitlik ilkesinden yola çıkarak bir tanımlamaya gidildiği söylenebilir. Zira hukuken eşit durumda olanlara eşit davranılmadığı ya da farklı durumda olanlara eşit davranıldığı ihtimalinde ayrımcılık gündeme gelecektir ${ }^{44}$.

Anayasa'da yer alan bu hükümlerin yanı sıra iç hukuk mevzuatımızda engellilerin ayrımcıllı̆g maruz kalmasını engellemeyi amaçlayan birçok hukuki düzenleme bulunmaktadır. Bu bağlamda ilk olarak bahsedilmesi gereken, Engelliler Hakkında Kanun olacaktır ${ }^{45}$. Yürürlüğe girdiği haliyle "Özürlüler ve Bazı Kanun ve Kanun Hükmünde Kararnamelerde Değişiklik Yapılması Hakkında Kanun" olan bu düzenlemenin ismi 25.04.2013 tarihli 6462 sayılı Kanun'un yürürlüğe girmesiyle birlikte "Engelliler Hakkında Kanun" olarak değiştirilmiştir. Ayrıca Kanun içerisinde yer alan "özürlüler" ibarelerinde "engelliler" olarak değişiklikler yapılmıştır. Engelli Hakları Komitesi’nin yukarıda da ifade edildiği gibi bu değişikliği olumlu karşıladığı bilinmektedir. Zira Komite, iç hukuk mevzuatının diline önem vermektedir ${ }^{46}$. Çünkü “özürlü” ibaresi, sözlük anlamı itibariyle "kusurlu, defolu” olarak tanımlanmaktadır. Bu sözlük anlamından dolayı kelimenin aşağılayıcı bir anlam ihtiva ettiği gerekçesiyle değiştirilmesi, olumlu görülmektedir.

Kanun'un 4. maddesi ve devamı ayrımcıllığa ilişsindir. Anayasa'da ayrımcılık yasağı ve eşitlik ilkesine ilişkin hususların bu Kanun'da da yinelendiği görülmektedir. Kanun'da 6518 sayılı Kanun'la yapılan değişiklikle getirilen ${ }^{47}$ 4/A maddesinin 2. ve 3. fikrasında "Eşitliği sağlamak ve ayrımcılı̆̆ı ortadan kaldırmak üzere engellilere yönelik makul düzenlemelerin yapılması için gerekli tedbirler alınır. Engellilerin hak ve özgürlüklerden tam ve eşit olarak yararlanmasını sağlamaya yönelik alınacak özel tedbirler ayrımcılık olarak değerlendirilemez." ifadeleri yer almaktadır. Bu ifadelerden iki önemli husus

\footnotetext{
42 Iş1l Gül, İdil/Karan, Ulaş. Ayrımcılık Yasağı, İstanbul Bilgi Üniversitesi Yay., İstanbul, 2011, s. 92; Kara, Bülent. "Türkiye'de Engelli Bireylerin Yasal Hakları ve Uygulamadaki Yeri”, International Journal of Social Science, S.48, 2016, s. 253.

43 AYM, 2017/156 E. 2019/37 K. Bkz. RG, 25.07.2019-30842.

44 Karan, Ulaş. "Bireysel Başvuru Kararlarında Ayrımcılık Yasağı ve Eşitlik İlkesi”, Anayasa Yargısı, S.32, 2015, s. 237.

$45 \quad 5378$ s. Kanun. Bkz. RG, 07.07.2005-25868.

46 Nitekim aynı hassasiyet, Engelli Hakları Sözleşmesi'nde de gösterilmekte engellileri aşağılanmaması adına kullanılan ifadelerin önemine dikkat çekilmektedir. Bkz. Çağlar, Selda. “Engelli Hakları Sözleşmesi’nde Ayrımcılık Yasağı ve Türkiye'nin Uyum Sorunu”, TBB Dergisi, S.96, 2011, s. 155.

476518 sayılı Aile ve Sosyal Politikalar Bakanlığının Teșkilat ve Görevleri Hakkında Kanun Hükmünde Kararname ile Bazı Kanun ve Kanun Hükmünde Kararnamelerde Değișiklik Yapılmasına Dair Kanun. Bkz. $R G, 19.02 .2014-28918$.
} 
anlaşılmaktadır. Bunlardan ilki 2. fikrada belirtilen gerekli tedbirlerin alınması meselesidir. Kanun "gerekli tedbirler alınır" diyerek emredici bir hüküm ortaya koymakta, devlete pozitif yükümlülükler getirmektedir. 3. fikrada belirtilen de bu düzenlemelerin ayrımcılık olmayacağına ilişkindir. Nitekim maddenin gerekçesinde de bu hususa tekrar değinilmiş, alınacak özel tedbirlerin ayrımcılık sayılmayacağının zaten Anayasa' yla da güvence altına alındığı belirtilmiştir ${ }^{48}$.

Engelli bireylere ilişkin özel tedbirlerin ayrımcılık sayılmayacağına ilişkin ilk olarak 657 sayılı Kanun'un 53. maddesi örnek verilebilir. Zira bu maddeye göre devlet kurum ve kuruluşlarının \%3 oranın engelli çalıştırma zorunluluğu bulunmaktadır ${ }^{49}$. Böylelikle yukarıda belirtilen, engellilere ilişkin özel tedbirlerin bir örneğinin verildiği söylenebilir.

Benzer biçimde İş Kanunu'nda da engellileri koruyan birtakım hükümler bulunmaktadır. 4857 sayılı İş Kanunu'nun 5. maddesi işverene eşit davranma yükümlülüğü getirmekte ve ayrım sebepleri içerisinde engellilik de sayılmakta, işverene engelliliğe dayalım ayrım yapma yasağı getirilmektedir. Ayrıca 30. madde ile elli ve üzeri işçi çalıştıran özel işyerlerinde $\% 3$ oranında engelli çalıştırma yükümlülüğ̈̈̈50 düzenlenmektedir ${ }^{51}$. Yine Milli Eğitim Temel Kanunu'nun 4. maddesi ${ }^{52}$ ve Türk Ceza Kanunu'nun 122. maddesinde ${ }^{53}$ engellilere yönelik ayrımcılığın yasaklandığı görülmektedir.

Söz konusu hükümler engellilere yönelik ayrımcılığın önlenmesini amaçlamış olmakla birlikte bazı kamu kurumlarına personel alımlarında ilgili kurumların işleyişine yönelik düzenlenen mevzuatta ayrımcılık teşkil edebilecek nitelikte hükümler de bulunmaktadır. Bu bağlamda Hakimler ve Savcılar Kanunu ilk olarak örnek verilebilir. Zira hakimlik ve savcılık mesleği adaylarının nitelikleri sayılırken 8 . maddenin (g) bendinde "Hakimlik ve savcllı görevlerini sürekli olarak yurdun her yerinde yapmasina engel olabilecek vücut ve akıl hastalığı veya engelliliği, alışılmışın dışında çevrenin yadırgayacağı şekilde konuşma ve organlarının hareketini kontrol zorluğu çekmek gibi engeli bulunmamak" şartı bulunmaktadır ${ }^{54}$. Benzer şekilde Dışişleri Bakanlığı Personeline İlişkin Bazı Düzenlemeler Hakkında Kanun'un 10. maddesinin 11. fikrasında da "Meslek memurları ile konsolosluk ve ihtisas memurlarının

48 T.C. Başbakanlık Kanunlar ve Kararlar Genel Müdürlüğü, https://www2.tbmm.gov.tr/d24/1/1-0796.pdf, (Erişim Tarihi: 12.04.2020).

657 s. Kanun, $R G, 23.07 .1965-12056$.

50 Söz konusu istihdam yükümlülüğünden faydalanması için bireyin, 14 yaşın üzerinde ve en az \%40 oranında engelli olması ve bu engelliliğinin Türkiye İş Kurumu tarafından tescillenmesi gerekmektedir. Bkz. Köme Akpulat, Ayşe. “İşverenin Engelli İşçi Çalıştırma Yükümlülüğü”, İHM, C.77, S.2, 2019, s. 540-541. İş Kanunu'nun ilk çıktığı hali için Bkz. 4857 s. Kanun, $R G, 10.06 .2003-25134$. Belirli oranda engellinin çalıştırılmasını öngören sisteme koruyucu istihdam sistemi adı verilmektedir. Bkz., Köme Akpulat, s. 535. 1739 s. Kanun, $R G, 24.06 .1973-14574$.

5237 s. Kanun'un Nefret ve Ayırımcılık başlıklı 122. maddesi şu şekildedir: "Madde 122- (Değişik: 2/3/2014-6529/15 md.)

(1) Dil, ırk, milliyet, renk, cinsiyet, engellilik, siyasi düşünce, felsefi inanç, din veya mezhep farklılığından kaynaklanan nefret nedeniyle;

a) Bir kişiye kamuya arz edilmiş olan bir taşınır veya taşınmaz malın satılmasını, devrini veya kiraya verilmesini,

b) Bir kişinin kamuya arz edilmiş belli bir hizmetten yararlanmasını,

c) Bir kişinin işe alınmasını,

d) Bir kişinin olağan bir ekonomik etkinlikte bulunmasını,

engelleyen kimse, bir yıldan üç yıla kadar hapis cezası ile cezalandırılır.” Görüldüğü üzere engelliliğe dayalı ayrımcılık Türk Ceza Kanunu tarafından yaptırıma tâbi tutulmaktadır. Bu maddeye ilişkin ayrıca belirtilmesi gereken husus, madde başlığında "ayırımcılık" ifadesinin kullanılmasıdır. Zira TDK tarafından belirlenen yazım kurallarına göre ünlü düşmesi sonucu "ayrımcılık" olarak yazılması gerekmektedir. 
Bakanlığa alınabilmeleri için tam teşekküllü bir Devlet hastanesinden verilen, her türlü iklim şartında görev yapabileceklerine dair rapor ibraz etmeleri gereklidir. Hukuk müşavirleri ile danışmanlardan da Bakanlığa alınmaları sırasında bu raporu ibraz etmeleri istenebilir." hükmü yer almaktadır ${ }^{55}$. Gerek hakimlik ve savcılığa ilişkin gerekse meslek memurları ile konsolosluk ve ihtisas memurluklarına ilişsin hüküm AİHM'nin de belirlediği sınır dahilinde devletlere bırakılan takdir marjı dahilinde görülebilirse de anılan hükümler, engellilerin kamu kurumlarındaki yüksek memurluklara ve yöneticiliklere atanması ihtimalinin zayıflaması sonucunu doğurabilir. Bu bağlamda söz konusu hükümlerde, ilgili mesleğin icra edilmesini engelleyecek hususların daha açık bir biçimde belirlenmesi gerekmektedir ${ }^{56}$.

\section{Makul Uyumlaştırma Beklentisi}

Makul uyumlaştırma kavramı ilk olarak ESKHS'nin 5 numaralı yorumunda dile getirilmektedir ${ }^{57}$. Söz konusu yorumda "makul uyumlaştırma (reasonable accommodation)"dan özellikle engellilerin toplumsal hayatta karşılaş̧ı̆̆ı zorluklara dayalı olarak bahsedilmektedir. Zira engellilerin karşılaştıkları zorlukların ortadan kaldırılabilmesi için söz konusu toplumsal alanlarda engellilerin ihtiyaçlarına yönelik bir tasarım yapılması gerekmektedir. Bu bağlamda hükümetlerin engellilere yönelik olarak onların toplumsal hayata katılımını artıracak makul uyumlaştırmaları teşvik etmesi gerektiği belirtilmektedir ${ }^{58}$.

Burada dikkat çekilecek husus, makul uyumlaştırmaların hükümetler tarafından teşvik edileceği hususudur. Başka bir ifadeyle hükümetlerin makul uyumlaştırma bakımından rolü pozitif yükümlülüğün yatay etkisi ile ilişkili gibi görünmektedir ${ }^{59}$. Makul uyumlaştırma (reasonable accommodation), ilgili kişi ya da kurumların alması gereken (örnek vermek gerekirse işyerinde işveren, eğitim alanında okul idaresi gibi), engellilerin kendi inisiyatiflerinde olmayan dezavantajlarını ortadan kaldırmaya yönelik tedbirlerdir ${ }^{60}$. Engelli Haklarına İlişkin Sözleşme'nin Resmî Gazete'de yayınlanan metninde Sözleşme'nin 2. maddesinin 3. ve 4. fikrası şu şekilde çevrilmiştir ${ }^{61}$ :

“'Engelliliğe dayalı ayrımcıllk' siyasi, ekonomik, sosyal, kültürel, medeni veya başka herhangi bir alanda insan hak ve temel özgürlüklerinin tam ve diğerleri ile eşit koşullar altında kullanılması veya bunlardan yararlanılması önünde engelliliğe dayalı olarak gerçekleştirilen her türlü ayrım, dışlama veya kısıtlamayı kapsamaktadır. Engelliliğe dayalı ayrımcılık makul düzenlemelerin gerçekleştirilmemesi dahil her türlü ayrımciliğ kapsar.

6004 s. Kanun, $R G, 13.07 .2010-27640$.

Bununla birlikte Avrupa'da birçok ülkenin de benzer şartları belirlediği görülmektedir. Fransa'da hâkim olabilmek için görevi yapmasına engel olmayacak fiziki koşullara ve sağlığa sahip olma şartı bulunmaktadır. Benzer şartın Romanya'da da olduğu görülmektedir. Avusturya'da da kanunen zorunlu olmamakla birlikte sağlık kontrolünün yerleşmiş bir uygulama olduğu belirtilmektedir. İspanya'da ise mesleği yapmasına engel teşkil etmeyen düzeyde engelli bireylere, durumlarına göre yapılmış sınavlardan başarılı olmaları halinde üçte bir oranında hâkim ve savcılık kontenjanı verildiği belirtilmektedir. Bkz. Avrupa Birliği Genel Müdürlügü. Avrupa Birliği Ülkelerinde Hâkimlik ve Savcllık Yüksek Yargı Organları Yargl Üst Kurulları, Editör: Fatih Denizkuşları, Ankara Açık Ceza İnfaz Kurumu Matbaası, Ankara, 2016, s. 30.

Lord, Janet E./Brown, Rebecca. "The Role Of Reasonable Accommodation In Securing Substantive Equality For Persons With Disabilities: The Un Convention On The Rights Of Persons With Disabilities", http://dx.doi.org/10.2139/ssrn.1618903, (Erişim Tarihi: 29.05.2020), s. 4.

General Comment No. 5: Persons with disabilities, E/1995/22, 9/12/1994, para. 22-23.

AİHM, yatay etki kavramını akit devletlerin sözleşmeden doğan hakları, herkese karşı koruma yükümlülüğünden kaynaklanmasıyla ilişkili kabul etmektedir. Dolayısıyla üçüncü kişilerin eylemlerinden doğan müdahaleler de akit devletin sorumluluğu altında olduğundan pozitif yükümlülüğünün yerine getirilip getirilmediği incelemesini mecburi kılar. Bkz. VgT Verein Gegen Tierfabriken/Ísviçre, B. No: 24699/94, 28/6/2001, para. 45.

Bkz. European Commission, "Reasonable accommodation for people with disabilities", https://ec.europa.eu/social/main.jsp?catId=1473, (Erişim Tarihi: 30.05.2020).

$R G, 14.07 .2009-27288$. 
'Makul düzenleme', engellilerin insan haklarını ve temel özgürlüklerini tam ve diğer bireylerle eşit şekilde kullanmasını veya bunlardan yararlanmasını sağlamak üzere belirli bir durumda ihtiyaç duyulan, ölçüsüz veya aşırı bir yük getirmeyen, gerekli ve uygun değisşiklik ve düzenlemeleri ifade eder."

Görüldüğü gibi makul uyumlaştırma kavramı, makul düzenleme olarak çevrilmektedir. Oysa Sözleşmenin asıl metninde reasonable accommodation ifadesi kullanılmaktadır ${ }^{62}$. "Düzenleme" kavramı sözleşmede adjustment kelimesine karşılık gelmektedir. Dolayısıyla makul uyumlaştırma ile makul düzenlemenin tam anlamıyla aynı ifadeler olduğu söylenemez ${ }^{63}$. Zira makul uyumlaştırma yapmanın yolu gerekli düzenlemelerin (adjustments) yapılmasına bağlıdır. Bu bakımdan düzenleme kavramı, makul uyumlaştırmanın gerçekleştirilebilmesinin bir yolu gibi görünmektedir.

Makul uyumlaştırmadan söz edilebilmesi için temelde şu üç hususa dikkat edilmektedir:

- İhtiyaç duyulan bir değişiklik olmalı: engelli ya da diğer dezavantajlı gruplardan birine mensup bireyin (zira makul uyumlaştırmanın yalnızca engelliler açısından olmadığı, diğer dezavantajlı grupları da kapsadığ kabul edilmektedir) $^{64}$ işyeri, okul vb. alanlarda sahip olduğu eksikliğin giderilmesi için gerekli olmalıdır. Örnek verilirse, işyerinde engelli kişiler için merdiven kullanamıyorsa rampa sisteminin kurulmas1.

- Ölçüsüz ve ağır yük getirmemeli ${ }^{65}$ : Örnek verilecek olursa eğitim verilen binanın ya da işyerinin engelli ya da diğer dezavantajlı bireylerin eksikliğini ortadan kaldırmak için alınması gereken tedbirlerle bütünüyle değiştirilmesi gibi ağır bir yük getiriyorsa makul uyumlaştırma kapsamında düşünülemez.

- Gerekli ve uygun değişiklikler yapılmalı: Yapılan değişikliğin söz konusu eksikliği gidermeye yönelik bir değişiklik olması gerekmektedir. Zira her engelli bireyin ihtiyacı birbirinden farklı olabilir ve türdeş bir yapı oluşturmak güç olabilir. Bu bakımdan yapılacak değişikliğin uygun değişiklik olması ve her engel için ayrı şekilde düzenlenmesi gerekmektedir. Elbette bu ayrı düzenleme gerekliliği, yukarıda belirtilen hususla da ilişkili olarak ölçüsüz ve ağır yük getirmemelidir ${ }^{66}$. Örnek verilecek olursa, çok katlı bir işyerinde çalışan engelli birey için rampa ya da asansör sistemlerinin yapılması ${ }^{67}$.

62 "Discrimination on the basis of disability' means any distinction, exclusion or restriction on the basis of disability which has the purpose or effect of impairing or nullifying the recognition, enjoyment or exercise, on an equal basis with others, of all human rights and fundamental freedoms in the political, economic, social, cultural, civil or any other field. It includes all forms of discrimination, including denial of reasonable accommodation;

'Reasonable accommodation' means necessary and appropriate modification and adjustments not imposing a disproportionate or undue burden, where needed in a particular case, to ensure to persons with disabilities the enjoyment or exercise on an equal basis with others of all human rights and fundamental freedoms;" "Bkz. Convention On The Rights Of Persons With Disabilities, https://treaties.un.org/doc/Publication/CTC/Ch_IV_15.pdf, (Erişim Tarihi: 30.05.2020). Çağlar'ın makul uyumlaştırma ile makul düzenlemeyi aynı kabul ettiği görülmektedir. Bkz. Çağlar, “Ayrımcılık Yasağı ve Türkiye'nin Uyum Sorunu”, s. 152. Tanay Aksaç, Gizem/Şenyurt Akdağ, Arzu. Ayrımcılık ve Engelli Hakları, Engelli Kadın Derneği, Ankara, 2015, s. 12; Degener, diğer dezavantajlı grupların da makul uyumlaştırma ihtiyacının olduğu ancak devletlerin makul uyumlaştırmaya yönelik tedbirlerinin genellikle engellilere ilişkin olduğunu ifade etmektedir. Bkz. Degener, Theresia. "Intersections between Disability, Race and Gender in Discrimination Law”, European Union Non-Discrimination Law and Intersectionality, Edited by Dagmar Schiek, Anna Lawson, Routledge Publishing, New York, 2016, s. 42.

65 Öğretide bu konunun ayrıntılı şekilde belirlenmesi gerektiği ifade edilmektedir. Zira hangi ihtiyacın yerine getirilmesinin ölçüsüz ve ağır yük getirdiğinin doğru tespit edilmesi gerekmektedir. Quinlivan, Shivaun. "Reasonable Accommodation: an Integral Part of the Right to Education for Persons with Disabilities", The Right to Inclusive Education in International Human Rights Law, Edited by Gauthier de Beco, Shivaun Quinlivan, Janet E. Lord, Cambridge University Press, Cambridge, 2019, s. 174. Quinlivan, s. 175.

67 Bojarski, Łukasz/Chopin, Isabelle/Cohen, Barbara/Do, Uyen/Farkas, Lilla/Iordache, Romanita. Ayrımcılık Yasă̆ı Ĕgitimi El Kitabı, İstanbul Bilgi Üniversitesi İnsan Hakları Hukuku Uygulama ve Araştırma Merkezi, 
Makul uyumlaştırmaya ilişkin dikkat çekilecek bir diğer husus, "pozitif ayrımcılık" kavramıyla karıştırılmaması gerekliliğidir ${ }^{68}$. Zira EHS'nin 2. maddesinin son fikrasında engellilere yönelik alınacak özel tedbirlerin ayrımcılık olmayacağı ifade edilmektedir. Burada esasen özel tedbirlerle kastedilenin öğretide pozitif ayrımcılık olarak bilinen kavrama denk düştüğü söylenebilir. İş Kanunu’nda kamu kurumlarının ve özel işyerlerinin belli oranda engelli çalıştırma yükümlülüğü bu pozitif ayrımcılık kavramı $^{69}$ dahilinde düşünülebilir. Makul uyumlaştırma ise yapılmadığı takdirde EHS'ye göre bir ayrımcılık ortaya çıkmaktadır ${ }^{70}$. Dolayısıyla makul uyumlaştırma ile pozitif ayrımcılık kavramları birbirinden farklı anlamlar içermektedir.

Söz konusu düzenlemeler bakımından, düzenleme yükümlülüğü bulunan kişi bilgilendirilmemişse, düzenleme yapılan kurum ya da kişiye söz konusu düzenlemeler ağır bir yük getiriyorsa, yapılacak düzenlemeler üçüncü kişilerin faaliyetlerini gereğinden fazla sınırlandırıyorsa ve düzenleme imkânsızlık içeriyorsa (yukarıda verilen işyerinin bütünüyle değiştirilmesi örneğinde olduğu gibi) uyumlaştırma yapılmadığı gerekçesiyle ayrımcılık yasağının ihlalinden söz edilemeyecektir ${ }^{71}$.

\section{SONUÇ}

Engellilere ilişkin yaklaşımın geçmişten bugüne değişimine bakıldığında, medikal modelden sosyal modele bir değişimin yaşandığ1 görülmektedir. Bu değişim esasen engellilerin toplum içerisinde nerede konumlandırıldığını anlamak adına önem arz etmektedir. Zira medikal modelde engellilere yönelik korumacı, başka bir deyişle onların bakıma muhtaç bireyler olduğu ön kabulüyle hareket edilmektedir. Sosyal modelde ise engellilerin topluma kazandırılmasını amaç edinen bir bakış açısından söz edilmektedir.

Engellilere yönelik bakış açısında meydana gelen değişim elbette hukuk düzeninde de birtakım değişiklikler yapılması ihtiyacını beraberinde getirmiştir. Zira kendi inisiyatiflerinde olmayan eksiklikler, engelli bireylerin toplumsal hayata dahil olmasını güçleştirmektedir. Ayrımcılık yasağı gerek Birleşmiş Milletler bünyesinde imzalanan diğer sözleşmelerle gerek Avrupa İnsan Hakları Sözleşmesi’yle düzenlenmişse de bu durum devletler için yeterli görülmemiştir. Engelli hakları daha spesifik bir sözleşmeyle korunmak istenmiş, Engelli Hakları Sözleşmesi Birleşmiş Milletler bünyesinde imzalanmış, böylece engellilere yönelik ayrımcılık yasağı da bu kapsamda güvence altına alınmıştır.

Birleşmiş Milletler bünyesinde imzalanan Ekonomik, Sosyal ve Kültürel Haklar Sözleşmesi'nin 5 numaralı genel yorumunda makul uyumlaştırma kavramına yer verilmiş olsa da EHS'nin imzalanması ile bu kavramın geliştiği görülmektedir. Bu kavram, yalnızca engelliler açısından değil aynı zamanda diğer dezavantajlı gruplar açısından da geçerli olan bir kavramdır. Zira dezavantajlı gruplara yönelik makul uyumlaştırmaların akit devletlerin iç hukuklarında yapılmaması ya da bu grupların toplumsal hayat içerisinde eksiklerinin giderilmemesi, makul uyumlaştırmanın yapılmadığı anlamına gelecektir ve ayrımcılık yasağına aykırılık teşkil edecektir. Makul uyumlaştırma kavramı bu bağlamda ayrımcılığın önlenmesi açısından önem arz etmektedir. Ayrıca makul uyumlaştırma ile düzenleme kavramları her ne kadar birbirinin yerine kullanılsa da EHS'ye göre tam olarak aynı anlama gelmemektedir. Nitekim sözleşmeye göre düzenleme, makul uyumlaştırmanın sağlanması için yapılması gereken hususlar olarak ifade edilebilir. Bir başka deyişle makul uyumlaştırma, düzenlemeler vasıtasıyla gerçekleştirilmektedir.

İstanbul, 2012, s. 30.

68 Quinlivan, s. 170.

69 Bu kavram da esasen eşit işlem yükümlülüğü kapsamında değerlendirilmekte, eşitsizliğin giderilmesi amacına hizmet etmektedir. Bkz. Ulucan, Devrim. "Eşitlik İlkesi ve Pozitif Ayrımcılık", DEÜHFD, C.15, 2013, s. 376

70 Ferri, Delia/Lawson, Anna. Reasonable Accommodation for Disabled People in Employment, Office of the European Union, Luxembourg, 2016, s. 48; Quinlivan, s. 173.

71 Iș1l Gül/Karan, Ayrımcılık Yasağl, s. 19-20. 
Dolayısıyla düzenleme kavramı makul uyumlaştırmanın sağlanması açısından kullanılan bir araç niteliğindedir.

\section{KAYNAKÇA}

Akbulut, Süleyman/Özgül, Hakan/Polat, Güler. Engelli Ayrımcllı̆̆ Araştırması ve Engelli Ayrımcllı̆̆ına Karşı Çözüm Önerileri Raporu, Engelli Ayrımcıllğını Önleme ve Mücadele Platformu, y.y., 2012.

Avrupa Birliği Genel Müdürlüğ̈̈. Avrupa Birliği Ülkelerinde Hâkimlik ve Savcllı Yüksek Yargl Organları Yargı Üst Kurulları, Editör: Fatih Denizkuşları, Ankara Açık Ceza İnfaz Kurumu Matbaası, Ankara, 2016.

Avrupa İnsan Hakları Sözleşmesi'ne Ek 12 Numaralı Protokol. https://humanrightscenter.bilgi.edu.tr/tr/content/62-avrupa-insan-haklar-sozlesmesine-ek-12-numaral-protokol/, (Erişim Tarihi: 22.05.2020).

Azarkan, Ezeli/Benzer, Ekrem. "Birleşmiş Milletler Engelli Kişilerin Haklarına Dair Sözleşme ve Türkiye'de Engelli Hakları", DÜHFD, C.23, S.38, 2018, s. 3-29.

Bojarski, Łukasz/Chopin, Isabelle/Cohen, Barbara/Do, Uyen/Farkas, Lilla/Iordache, Romanita. Ayrımcllk Yasağı Ĕgitimi El Kitabl, İstanbul Bilgi Üniversitesi İnsan Hakları Hukuku Uygulama ve Araştırma Merkezi, İstanbul, 2012.

Committee on Economic, Social and Cultural Rights. "General Comment No. 5: Persons with disabilities", $\mathrm{E} / 1995 / 22$,

https://tbinternet.ohchr.org/_layouts/15/treatybodyexternal/Download.aspx?symbolno=INT\%2fCESCR\%2fGEC\%2f 4760\&Lang=en, (Erişim Tarihi: 25.06.2020).

Committee on The Rights of Persons with Disabilities. "Engelli Hakları Komitesi Bekleyen Davalar Tablosu", https://www.ohchr.org/Documents/HRBodies/CRPD/Tablependingcases.pdf, (Erişim Tarihi: 24.05.2020).

Committee on the Rights of Persons with Disabilities. "Initial report submitted by Turkey under article 35 of the Convention, due in 2011", http://docstore.ohchr.org/SelfServices/FilesHandler.ashx?enc=6QkG1d\%2fPPRiCAqhKb7yhsvOO0RvDbzSfy057\% 2flfh1Ry2YlpRMLI6465IjBrNt3vxg8t5onRXsx\%2fl6Fgx5BA9r3D7yvTBoO2fizSv6CJipTSKPojwMGO64V\%2bP cRxItSGN, (Erişim Tarihi: 03.04.2020).

Convention On The Rights Of Persons With Disabilities. https://treaties.un.org/doc/Publication/CTC/Ch_IV 15.pdf, (Erişim Tarihi: 30.05.2020).

Çağlar, Bakır. "Anayasa Yargısında Yorum Problemi Karşılaştırmalı Analizin Katkıları", Anayasa Yargısl, C.2, 1985, s. 3-34.

Çağlar, Selda. "Engelli Hakları Sözleşmesi'nde Ayrımcılık Yasağı ve Türkiye'nin Uyum Sorunu", TBB Dergisi, S.96, 2011, s. 149-178.

Çelik, Elif. "Onuncu Yılında Birleşmiş Milletler Engelli Kişilerin İnsan Hakları Sözleşmesi ve Sözleşme Ruhu”, INÜHFD, C.7, S.1, 2016, s. 219-246.

Degener, Theresia. "Intersections between Disability, Race and Gender in Discrimination Law", European Union Non-Discrimination Law and Intersectionality, Edited by Dagmar Schiek, Anna Lawson, Routledge Publishing, New York, 2016, s. 29-47.

Engelli Hakları Komitesi. "Türkiye'nin İlk Raporuna İlişkin Nihai Gözlemler", http://www.tohad.org/tohad/wp-content/uploads/2019/05/bmehs_nihai_gozlem_raporu_2019.pdf, (Erişim Tarihi: 04.04.2020).

Erdoğan, Gülnur. “Avrupa Sosyal Şartı ve Gözden Geçirilmiş Avrupa Sosyal Şartı”, TBB Dergisi, S.77, 2008, s. $123-165$.

Erten, Şerafettin/Aktel, Mehmet. "Engellilik Kültürü: Engellilik Modelleri Çerçevesinde Bir Değerlendirme", Sosyal Bilimlerde Kültür Tartışmaları, Editör: Cem Ergun, Süleyman Öğrekçi, Gece Kitaplı̆̆ı, Ankara, 2017, s. 7996.

European Commission. "Reasonable accommodation for people with disabilities", https://ec.europa.eu/social/main.jsp?catId=1473, (Erişim Tarihi: 30.05 .2020 ).

Ferri, Delia/Lawson, Anna. Reasonable Accommodation for Disabled People in Employment, Office of the European Union, Luxembourg, 2016. 
Hukuki Haber. https://www.hukukihaber.net/mesleki-hukuk/gorme-engelli-hkim-adayinin-hukuk-zaferi-

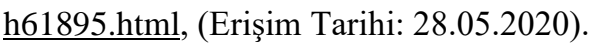

Işıl Gül, İdil/Karan, Ulaş. Ayrımcılık Yasă̆ı, İstanbul Bilgi Üniversitesi Yay., İstanbul, 2011.

Işıl Gül, İdil. "Birleşmiş Milletler Engelli Hakları Sözleşmesi”, Engellilik ve Ayrımcılık, Hazırlayanlar: Kenan Çayır, Melisa Soran, Melike Ergün, Karekök, İstanbul, 2015, s. 31-44.

Kara, Bülent. “Türkiye'de Engelli Bireylerin Yasal Haklar1 ve Uygulamadaki Yeri”, International Journal of Social Science, S.48, 2016, s. 249-260.

Karan, Ulaş. "Bireysel Başvuru Kararlarında Ayrımcılık Yasağı ve Eşitlik İlkesi”, Anayasa Yargısı, S.32, 2015, s. 235-306.

Köme Akpulat, Ayşe. “İşverenin Engelli İşçi Çalıştırma Yükümlülüğü”, IHHM, C.77, S.2, 2019, s. 523-553.

Lord, Janet E./Brown, Rebecca. "The Role Of Reasonable Accommodation In Securing Substantive Equality For Persons With Disabilities: The Un Convention On The Rights Of Persons With Disabilities", http://dx.doi.org/10.2139/ssrn.1618903, (Erişim Tarihi: 29.05.2020).

Sağlam, Fazıl. Temel Hakların Sınırlanması ve Özü, AÜSBF Yay., Ankara, 1982.

T.C. Başbakanlık Kanunlar ve Kararlar Genel Müdürlüğü. https://www2.tbmm.gov.tr/d24/1/1-0796.pdf, (Erişim Tarihi: 12.04.2020).

T.C. Dışişleri Bakanlığı Avrupa Birliği Başkanlığı. “Avrupa Komisyonu Tarafından Hazırlanan Türkiye Raporları”, https://www.ab.gov.tr/ilerleme-raporlari_46224.html, (Erişim Tarihi: 22.05.2020).

T.C. Dışişleri Bakanlığı Avrupa Birliği Başkanlığı. "Türkiye’nin Avrupa Birliğine Katılım Sürecine İlişkin

2003 Y1lı İlerleme Raporu”,
https://www.ab.gov.tr/files/AB_Iliskileri/AdaylikSureci/IlerlemeRaporlari/Turkiye_Ilerleme_Rap_2003.pdf, (Erişim Tarihi: 22.05.2020).

T.C. Dışişleri Bakanlığı Avrupa Birliği Başkanlığı. "Türkiye’nin Katılım Yönünde İlerlemesi Üzerine Komisyon'un 2000 Düzenli

Raporu", https://www.ab.gov.tr/files/AB_Iliskileri/AdaylikSureci/IlerlemeRaporlari/Turkiye_Ilerleme_Rap_2000.pdf, (Erişim Tarihi: 22.05.2020).

Tanay Aksaç, Gizem/Şenyurt Akdağ, Arzu. Ayrımcılık ve Engelli Hakları, Engelli Kadın Derneği, Ankara, 2015.

Ulucan, Devrim. "Eşitlik İlkesi ve Pozitif Ayrımcıllk”, DEÜHFD, C.15, 2013, s. 369-384.

Uyar, Lema. Birleșmiş Milletler'de İnsan Hakları Yorumları, İstanbul Bilgi Üniversitesi Yay., İstanbul, 2006.

Quinlivan, Shivaun. "Reasonable Accommodation: an Integral Part of the Right to Education for Persons with Disabilities", The Right to Inclusive Education in International Human Rights Law, Edited by Gauthier de Beco, Shivaun Quinlivan, Janet E. Lord, Cambridge University Press, Cambridge, 2019, s. 169-189.

\section{MAHKEME KARARLARI LISTESI}

AYM, 2017/156 E. 2019/37 K., $R G, 25.07 .2019-30842$.

Bayrakçı/Türkiye, B. No: 2643/09, 5/2/2013.

Botta/Italya, B. No: 153/1996/772/973, 24/2/1998.

Çam/Türkiye, B. No: 51500/08, 23/2/2016.

Glor/İsviçre, B. No: 13444/04, 30/4/2009.

VgT Verein Gegen Tierfabriken/İsviçre, B. No: 24699/94, 28/6/2001. 